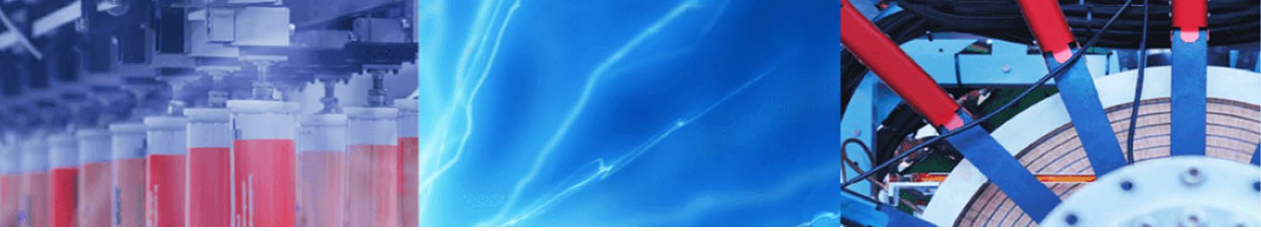

Research Article

\title{
Analysis of the mechanical strength, structure and possibilities of using waste phosphogypsum in aluminum powder composites
}

\author{
M. Wędrychowicz ${ }^{1}$ (D) A. W. Bydałek ${ }^{1,2} \cdot$ T. Skrzekut $^{3} \cdot$ P. Noga ${ }^{3} \cdot$ I. Gabryelewicz $^{1} \cdot$ P. Madej $^{4}$
}

C The Author(s) 2019 OPEN

\begin{abstract}
This paper presents the results of research on the effect of hydrated calcium sulfate (phosphogypsum) on the mechanical properties of composite based on aluminum powder. The phosphogypsum used is a by-product obtained in the phosphate fertilizers industry, e.g., at the Gdańskie Zakłady Fosforowe "Fosfory."The amount of phosphogypsum produced in Poland must be reduced due to the high costs of its storage and environmental protection. One of the ways to dispose of it is to use it as a filler in composite rods based on aluminum powder. The amount of phosphogypsum added was $2 \%$ and $5 \%$ by weight in relation to the aluminum powder's weight. The filled composite was subjected to strength tests to show whether phosphogypsum improves the mechanical properties of aluminum rods. Based on the results obtained, it was revealed that phosphogypsum used as a filler causes similar changes in the mechanical properties as mineral fillers described in the literature. Based on analyses of market potential, it can be easily assumed that there is a significant demand for the results of research on the use of phosphogypsum. The end of the article summarizes the discussed issue, emphasizing that solutions are sought for the use of phosphogypsum.
\end{abstract}

Keywords Composites $\cdot$ Hydrated phosphogypsum $\cdot$ Composite filler $\cdot$ Heat treatment $\cdot$ By-product

\section{Introduction}

There are three plants manufacturing phosphoric acid in Poland, and they are: Zakłady Chemiczne "Police" S.A., Gdańskie Zakłady Nawozów Fosforowych "Fosfory"S.A. and Zakłady Chemiczne "Alwernia" S.A. The first two plants produce a by-product in the form of hydrated phosphogypsum during the production of phosphoric acid $\left(\mathrm{CaSO}_{4} \cdot 2 \mathrm{H}_{2} \mathrm{O}\right)$. It is estimated that the production of 1 ton of fertilizer from phosphoric acid generates 4-5 tons of phosphogypsum, which is transported by barges to the heap in Wiślinka (near Gdańsk) [1]. Currently, there are about 25 million tonnes of this waste. At first, the landfill was $10 \mathrm{~m}$ high, and $40 \mathrm{~m}$ would be considered a critical value. In 2007, the heap reached $50 \mathrm{~m}$ and grew with each passing week. According to Polish-Finnish researchers, in 2013, in some places of the Martwa Wisła (in Wiślinka), the concentration of phosphates exceeded the permissible standard 12-fold [2]. Due to the lack of appropriate safeguards, rainwater seeping through the heap rinses out the harmful fluoride, which then enters ground and surface waters and the riverbed of Martwa Wisła [3].

The primary component of phosphogypsum is calcium sulfate dihydrate, which accounts for approx. $95 \%$ by weight and the remaining $5 \%$ are impurities, e.g., fluorine or trace amounts of heavy metals, i.e., $\mathrm{Cd}, \mathrm{Cr}, \mathrm{Ni}, \mathrm{Cu}, \mathrm{Zn}, \mathrm{Pb}$, etc. Phosphogypsum is a bulk material with a solubility of $2 \mathrm{~g} / \mathrm{l}$ with acidic $\mathrm{pH}(\mathrm{pH}<3)$. The amount of phosphogypsum produced in the USA annually is 50 million tons;

M. Wędrychowicz, mwedrychowicz@uz.zgora.pl | ${ }^{1}$ Faculty of Mechanical Engineering, University of Zielona Góra, ul. Prof. Z. Szafrana 4, 65-516 Zielona Gora, Poland. ${ }^{2}$ Maritime University of Szczecin, ul. Wały Chrobrego 1-2, 70-500, Szczecin, Poland. ${ }^{3}$ Faculty of Non-Ferrous Metals, AGH University of Science and Technology, al. A. Mickiewicza 30, 30-059 Kraków, Poland. ${ }^{4}$ Pyrometallurgy Department, Institute of Non-Ferrous Metals, ul. Sowińskiego 5, 44-100 Gliwice, Poland. 
in Morocco-14 million tons; in the Netherlands over 4 million tons and in Poland excess of 1.5 million tons [4-6].

\section{Problem analysis}

Calcium sulfate dihydrate in the form of gypsum or phosphogypsum can be used in thermoplastic polymer composites as a filler and a modifier. Depending on its amount and on the presence of other additives, calcium sulfate causes increased strength, hardness, abrasion resistance, as well as reduced flammability and press shrinkage [7, 8]. Calcium sulfate, also combined with other mineral fillers, can be used for chemo-setting floor and coating masses $[9,10]$. The amount of phosphogypsum consumed for composites is minute, usually from 4 to $6 \mathrm{~g}$. The main issue about phosphogypsum is its large-scale use and management. It could be used as a building material, but it has a cheaper and cleaner competitor in the form of construction gypsum. Moreover, the amount of construction gypsum used in construction is excessive. Attempts to use phosphogypsum to build roads as a coating in the artificial substrate layer led to asphalt cracking because phosphogypsum absorbed moisture and hardened the artificial layer in its cemented form [11, 12]. It seems that phosphogypsum could be successfully used in metallurgy. Since phosphogypsum is $70-80 \%$ hydrated calcium sulfate, it could replace, for example, calcium carbonate added to the decopperisation of suspension slag. An additional advantage of using phosphogypsum in steel mills is its quantity, i.e., several hundred tons per smelt. On the other hand, the content of heavy metals and sulfates could disturb the process of copper recovery from slag and degrade its physicochemical properties, and the sulfur bound to phosphogypsum would make its way into the alloy [13].

The aim of this paper was to determine the effect of adding phosphogypsum to a composite based on aluminum powder on the mechanical or other properties that enable its use for industrial and utility products. A view of the current phosphogypsum heap in Poland is shown in Fig. 1.

\section{Materials and methods}

As a basic filler, aluminum powder with $2 \%$ added waste phosphogypsum from the Recycling Plant Eko Harpoon sp. $z$ o.o. was used. Its composition is shown in Table 1. The analysis of the chemical composition of phosphogypsum was carried out using an X-ray fluorescence spectrometer with energy dispersion type: MiniPal with an analytical area from $\mathrm{Na}$ to $\mathrm{U}$, fitted with $\mathrm{Rh}$ lamp with a voltage range from 4 to $30 \mathrm{kV}$. The measurements were carried out

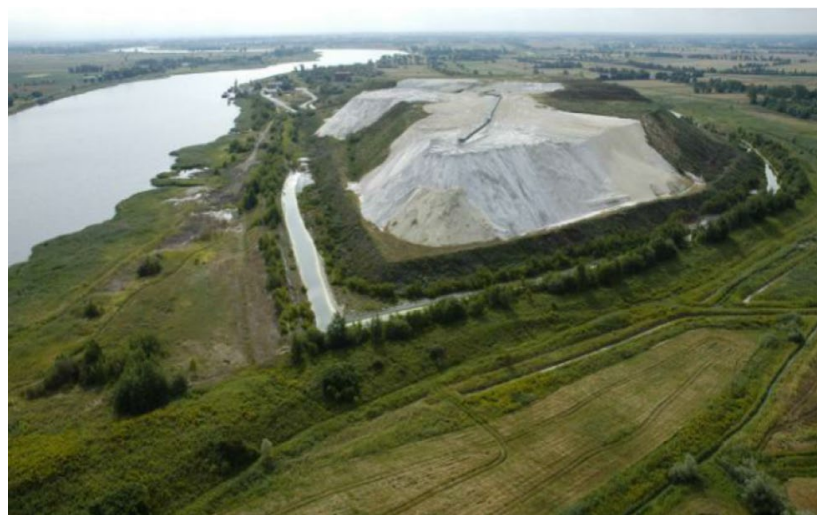

Fig. 1 A phosphogypsum heap in Wiślinka from Gdańskie Zakłady Nawozów Fosforowych "Fosfory" S.A.

Table 1 Major components of waste phosphogypsum obtained from the Recycling Plant Eko Harpoon sp. z o.o.

\begin{tabular}{ll}
\hline Ingredient & $\begin{array}{l}\text { Phosphogyp- } \\
\text { sum [\% by } \\
\text { weight }\end{array}$ \\
\hline $\mathrm{Ca}$ as $\mathrm{CaSO}_{4}$ & 69.5 \\
$\mathrm{P}$ as $\mathrm{P}_{2} \mathrm{O}_{5}$ & 2.9 \\
$\mathrm{~K}$ as $\mathrm{K}_{2} \mathrm{O}$ & 0.5 \\
$\mathrm{Na}$ as $\mathrm{Na}_{2} \mathrm{O}$ & 0.89 \\
$\mathrm{Si}$ as $\mathrm{SiO}_{2}$ & 1.7 \\
Fe as $\mathrm{Fe}_{2} \mathrm{O}_{3}$ & 2.51 \\
Other including water & 22 \\
\hline
\end{tabular}

at $298 \mathrm{~K}$, in helium atmosphere, for $100 \mathrm{~s}$. Controlling the camera's work and spectral analysis were conducted based on the MiniPal/MiniMate 2.0A software. The research program included the following experiments:

- Microstructure study of rods with $2 \%$ and $5 \%$ added phosphogypsum

- Strength testing of rods with the addition of a filler and a rod without added phosphogypsum.

The starting material for the tests was aluminum powder and phosphogypsum powder (Table 1). The TURBULA mixer was used to mix the following: $210 \mathrm{~g}$ of aluminum powder with $4.2 \mathrm{~g}$ of phosphogypsum powder and $210 \mathrm{~g}$ of aluminum powder with $10.5 \mathrm{~g}$ of phosphogypsum powder. The mixing process lasted $1 \mathrm{~h}$. The next stage of preparation involved compacting the powder on a hydraulic press with a maximum piston pressure of $100 \mathrm{tf}$. The aluminum powder and phosphogypsum mixture (Fig. 2) in the form of $30 \mathrm{~g}$ weighed sample were placed in a cylindrical press chamber, and then, the piston stamped the material with a pressure of $30 \mathrm{tf}$. This way, seven moldings 


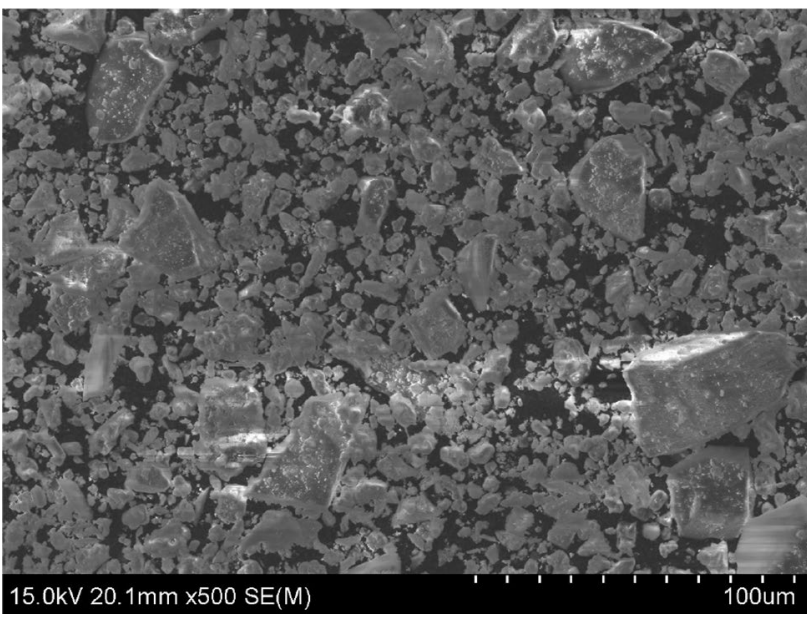

Fig. 2 Morphology of aluminum powder with phosphogypsum

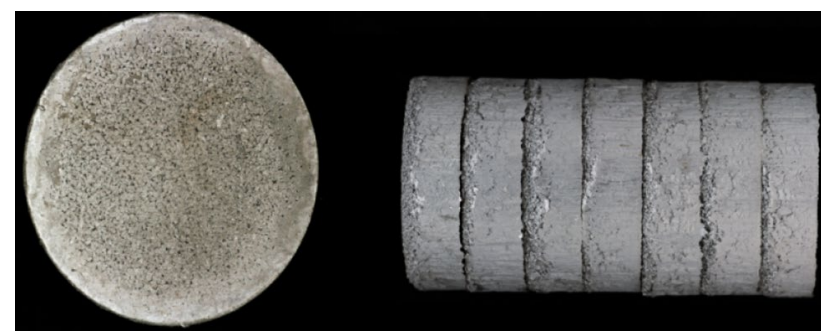

Fig. 3 Molding with added 2\% phosphogypsum of $38 \mathrm{~mm}$ diameter, with aluminum powder subjected to hot extrusion at a temperature of $350{ }^{\circ} \mathrm{C}$

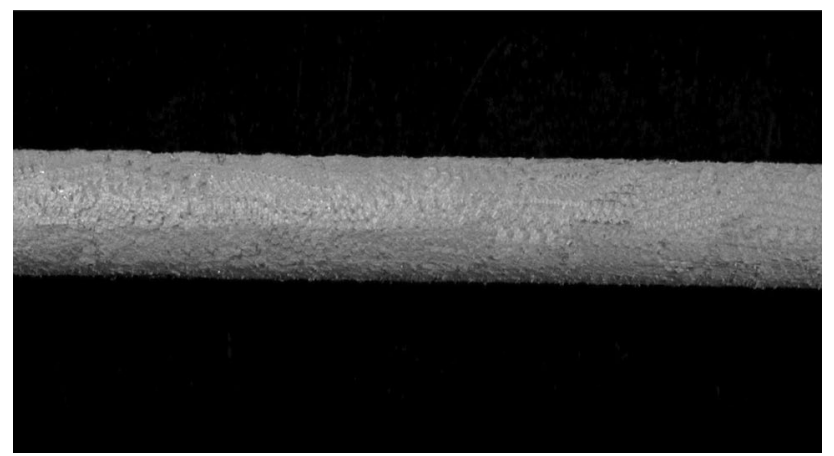

Fig. 4 Composite rod based on aluminum with $2 \% \mathrm{CaSO}_{4} \cdot 2 \mathrm{H}_{2} \mathrm{O}$ extruded at $350^{\circ} \mathrm{C}$

(Fig. 3) were obtained, with a diameter of $38 \mathrm{~mm}$ and a height of $10 \mathrm{~mm}$, which constituted the batch for the extrusion process. Such prepared batches were extruded using the concurrent method at $350^{\circ} \mathrm{C}$ at an extrusion speed of $3 \mathrm{~mm} / \mathrm{s}$ to obtain rods with a diameter of $8 \mathrm{~mm}$ (Figs. 4, 5). For comparison, a rod was extruded from aluminum powder under the same conditions.

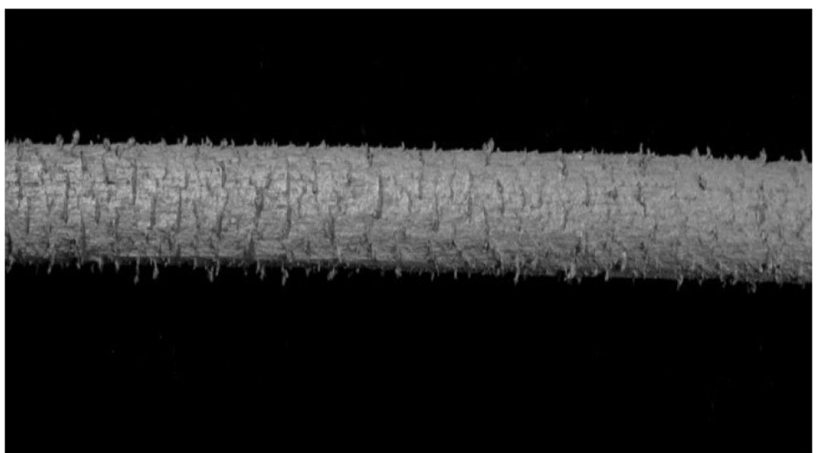

Fig. 5 Composite rod based on aluminum with $5 \% \mathrm{CaSO}_{4} \cdot 2 \mathrm{H}_{2} \mathrm{O}$ extruded at $350^{\circ} \mathrm{C}$

Table 2 Content of heavy metals in phosphogypsum

\begin{tabular}{lc}
\hline Type of metal & $\begin{array}{c}\text { Metal content } \\
\text { [\% by weight] }\end{array}$ \\
\hline $\mathrm{Pb}$ & 0.015 \\
$\mathrm{Ba}$ & 0.02 \\
$\mathrm{Sb}$ & 0.021 \\
$\mathrm{Cr}$ & $<0.004$ \\
$\mathrm{Cd}$ & $<0.005$ \\
$\mathrm{As}$ & $<0.003$ \\
$\mathrm{Hg}$ & $<0.008$ \\
$\mathrm{Zn}$ & 0.03 \\
\hline
\end{tabular}

Tensile strength testing of rods was determined by performing the uniaxial stretching test (Zwick/Roel Z050) at ambient temperature in accordance with EN ISO 6892-1. Microstructural observations were made using the Hitachi SU-70 scanning electron microscope.

\section{Results}

Based on the chemical composition from Table 1, it was revealed that the obtained waste phosphogypsum is $70 \%$ hydrated calcium sulfate with the addition of other salts, mainly phosphates and trace amounts of heavy metals. Most likely, phosphogypsum takes the form of calcined gypsum during extrusion at $350^{\circ} \mathrm{C}$ and pressure of $100 \mathrm{MPa}$, which binds aluminum powder together and fills its spaces well. The $2 \%$ added phosphogypsum has a smooth and matt surface. With more than $2 \%$ additive, it obtains a porous surface. For phosphogypsum to play the role of filler in composites, it must contain traces of heavy metals. The content of heavy metals in waste phosphogypsum is shown in Table 2.

According to standards, the content of waste phosphogypsum is suitable as a filler for composites because it does not exceed the limit values $[14,15]$. 
The plastic consolidation of aluminum powder and phosphogypsum powder by high-temperature extrusion allowed obtaining a composite with good surface quality; however, it should be emphasized that in the case of a $2 \%$ phosphogypsum composite, the surface is much better and has no defects such as cracks or delamination. The mechanical properties of the extruded rods were tested in a tensile test [16]. A rod extruded from aluminum powder has a tensile strength of $95 \mathrm{MPa}$, while the total elongation is approx. $65 \%$. The added amount of $2 \%$ phosphogypsum caused an increase in tensile strength to approx. $11 \mathrm{MPa}$, while decreasing the total elongation to the value below $60 \%$. Comparable plasticity is shown by a composite with $5 \%$ added phosphogypsum (Fig. 6) with a few percent decrease in tensile strength with respect to a composite with $2 \%$ phosphogypsum content (Fig. 7).

Structural analyses carried out at the fracture surfaces of strength samples using the SEM method showed a tendency to increase the porosity as the amount of phosphogypsum additive was increased (Fig. 8).

The analysis of fractures in the micro-regions (Fig. 9) has shown incorporation of phosphogypsum agglomerations of about 2-20 $\mu \mathrm{m}$ in the center of the compressed aluminum powder structure; it was determined that the total size of these phosphogypsum agglomerations is proportional to the amount of aluminum added into the powder [17]. In samples containing $2 \%$ phosphogypsum, these aggregations have a size of about 2-8 $\mu \mathrm{m}$ (Fig. 9a), while those containing $5 \%$ phosphogypsum have aggregations that are similar in size, i.e., 4-10 $\mu \mathrm{m}$ (Fig. 9b). In some extreme places, they reach a size of over $80 \mu \mathrm{m}$ (Fig. 9c). The analysis of the topography of composite fractures after a tensile test was conducted to determine whether the plastic consolidation process under the assumed temperature-velocity conditions is an effective method of obtaining as much material consistency as possible.
Fig. 6 Dependence of yield strength on deformation for a rod based on aluminum powder, and a rod based on aluminum powder with added $2 \%$ and $5 \%$ of phosphogypsum extruded at a temperature of $350^{\circ} \mathrm{C}$

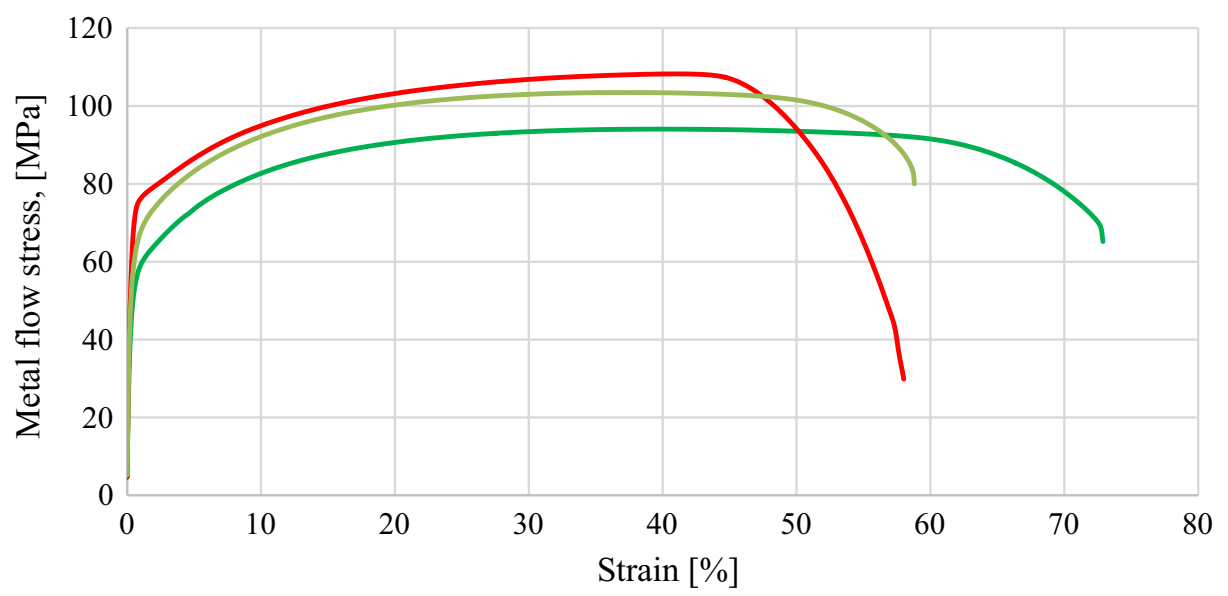

_ Aluminium powder

$\mathrm{Al}+2 \%$ phosphogypsum $\mathrm{Al}+5 \%$ phosphogypsum

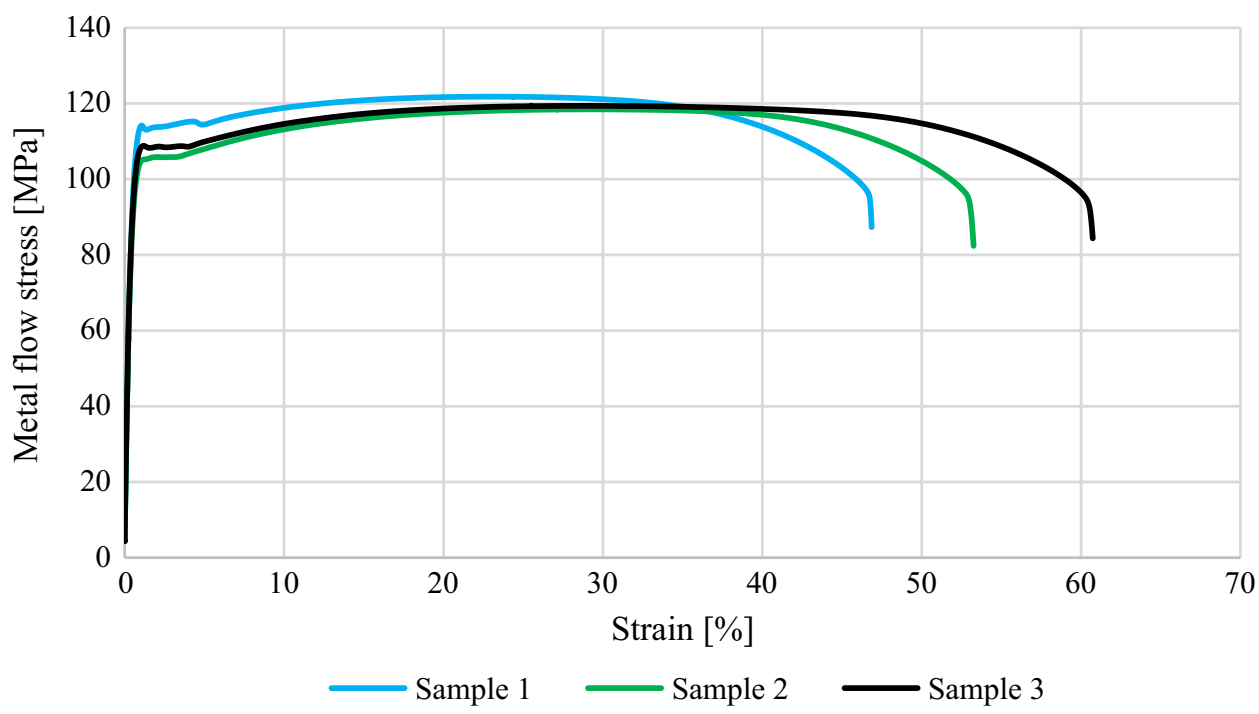

Fig. 7 Dependence of yield strength on deformation in three tensile tests for aluminum powder-based composite, extruded at $350{ }^{\circ} \mathrm{C}$ and with $2 \%$ added phosphogypsum
SN Applied Sciences 

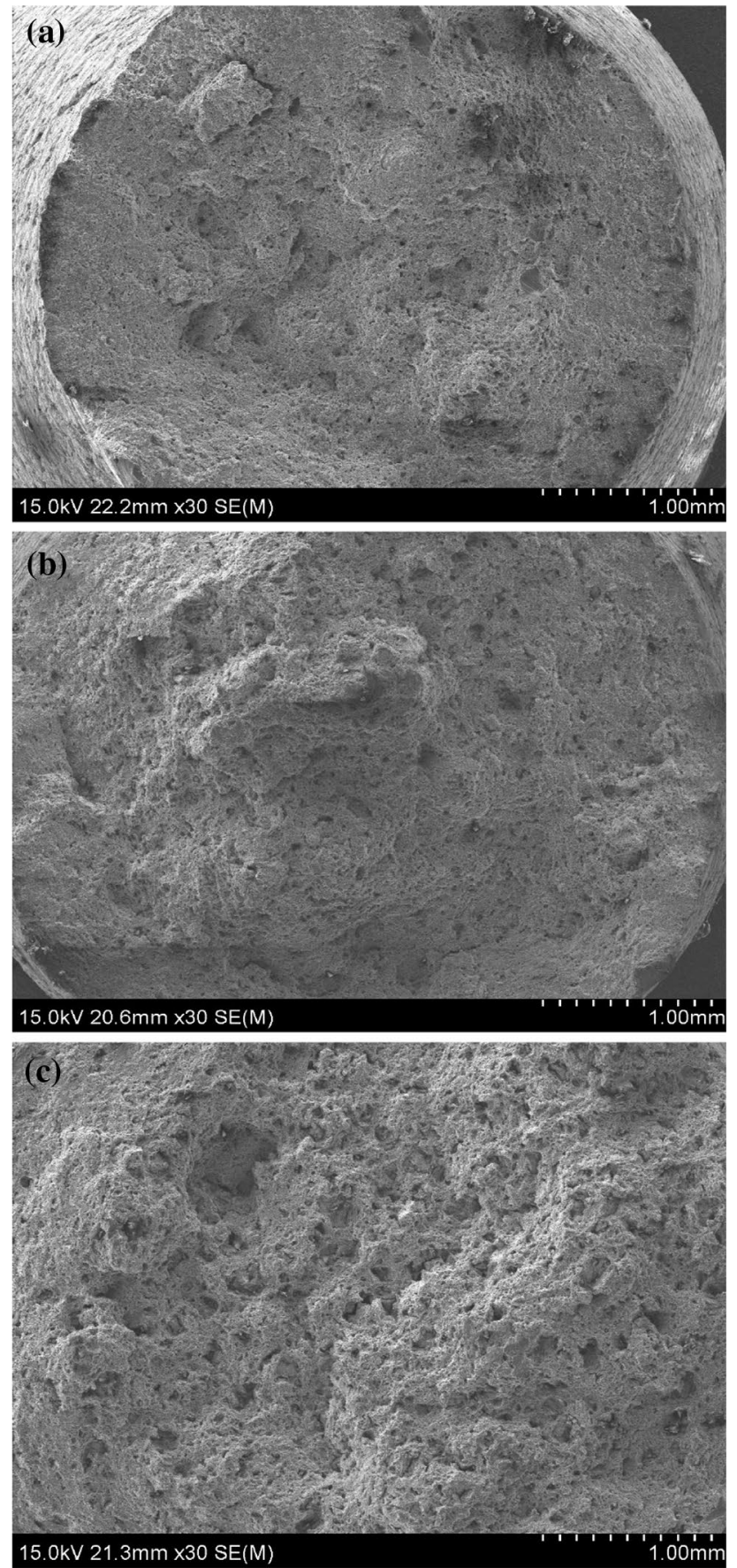

Fig. 8 Topography of the fracture surface of a rod extruded from aluminum powder: a with no added phosphogypsum, b with added $2 \%$ phosphogypsum, c with added $5 \%$ phosphogypsum $(\times 30$ magnification)

The composite material in Fig. 9 is characterized by a ductile fracture with a large number of microvoids throughout the observed surface. A large number of caverns at the fracture surface are typical for materials showing a tendency to ductile cracking. Phosphogypsum particles can be observed in the phosphogypsum-containing
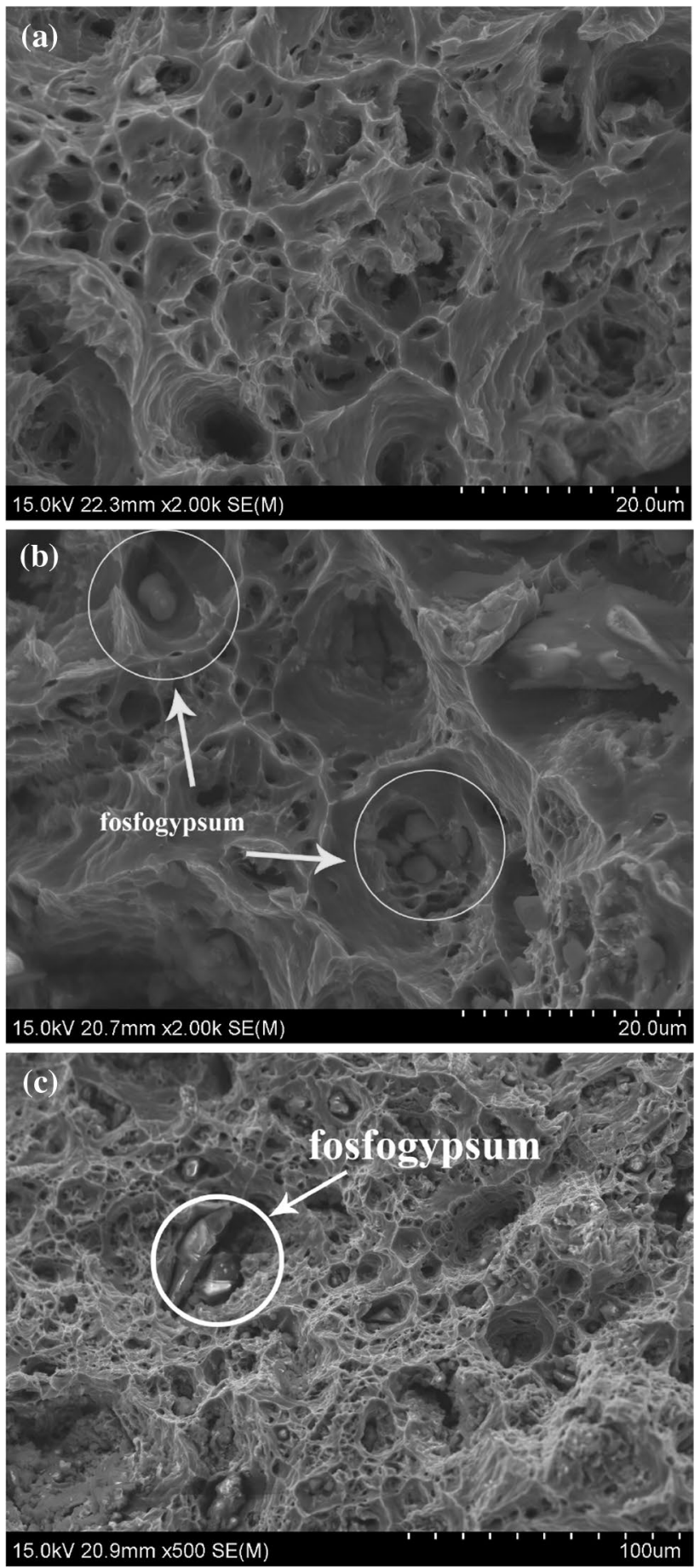

Fig. 9 Topography of the fracture surface of a composite extruded from aluminum powder: $\mathbf{a}$ with no added phosphogypsum, $\mathbf{b}$ with added $2 \%$ phosphogypsum, c with added $5 \%$ phosphogypsum ( $\times 2000$ magnification)

composites, which are located inside the caverns. Another effect of adding phosphogypsum to aluminum powder is the change in the size of caverns, closed cellular voids that make up the structure of the compressed powder. During 
the tests, it was observed that the average size of the diagonals of these caverns increased, while the number of small caverns was reduced after adding phosphogypsum. The structure of clean, compressed aluminum powder is a diverse one, containing both small cavities with dimensions of 4-6 $\mu \mathrm{m}$ (approx. $60 \%$ of volume) and large, heavily fragmented cavities with dimensions of 8-12 $\mu \mathrm{m}$ (approx. $40 \%$ of volume). Moreover, a change in the morphology of cavern walls with phosphogypsum material was observed. The walls have a clearly cellular structure, are extensive, and exhibit a spontaneously formed network structure. This type of structure may explain the strength effects obtained in these samples, despite the presence of large clusters of fragile phosphogypsum fractions in them. One may put forward a thesis that the formation of such a separate structure of cavern walls after adding phosphogypsum is largely determined by surface phenomena due to the presence of elements such as calcium and magnesium. The shape of phosphogypsum agglomerations-clearly spherical-may also provide evidence of the possibility of a strong effect of surface impacts during the formation of the cavern structure. Furthermore, the balance of the number of phosphogypsum agglomerations in built-in caverns and the results of EDS analysis (Fig. 10) indicate that a certain amount of phosphogypsum was mixed or even dissolved due to the temperature during the pressing process in Al powder. The end result of this treatment is the emergence of a new cellular structure of cavern walls, as shown in Fig. 11.

\section{Conclusion}

The proposed uses of waste phosphogypsum are beneficial due to:

- environmental protection (use of post-production waste from the chemical industry),

- elimination of landfilling charges by Gdańskie Zakłady Nawozów Fosforowych "Fosfory" S.A. and Eko Harpoon sp.zo. o.

The obtained composite's strength parameters resemble those of 1050A-grade aluminum rods, which show good mechanical properties and could probably be cheaper substitutes. Finally, it should be highlighted that despite the effective use of phosphogypsum in the composite in the amount of $2 \%$, i.e., approx. $4.2 \mathrm{~g}$ of powder, using such a quantity cannot cover the need for its disposal.

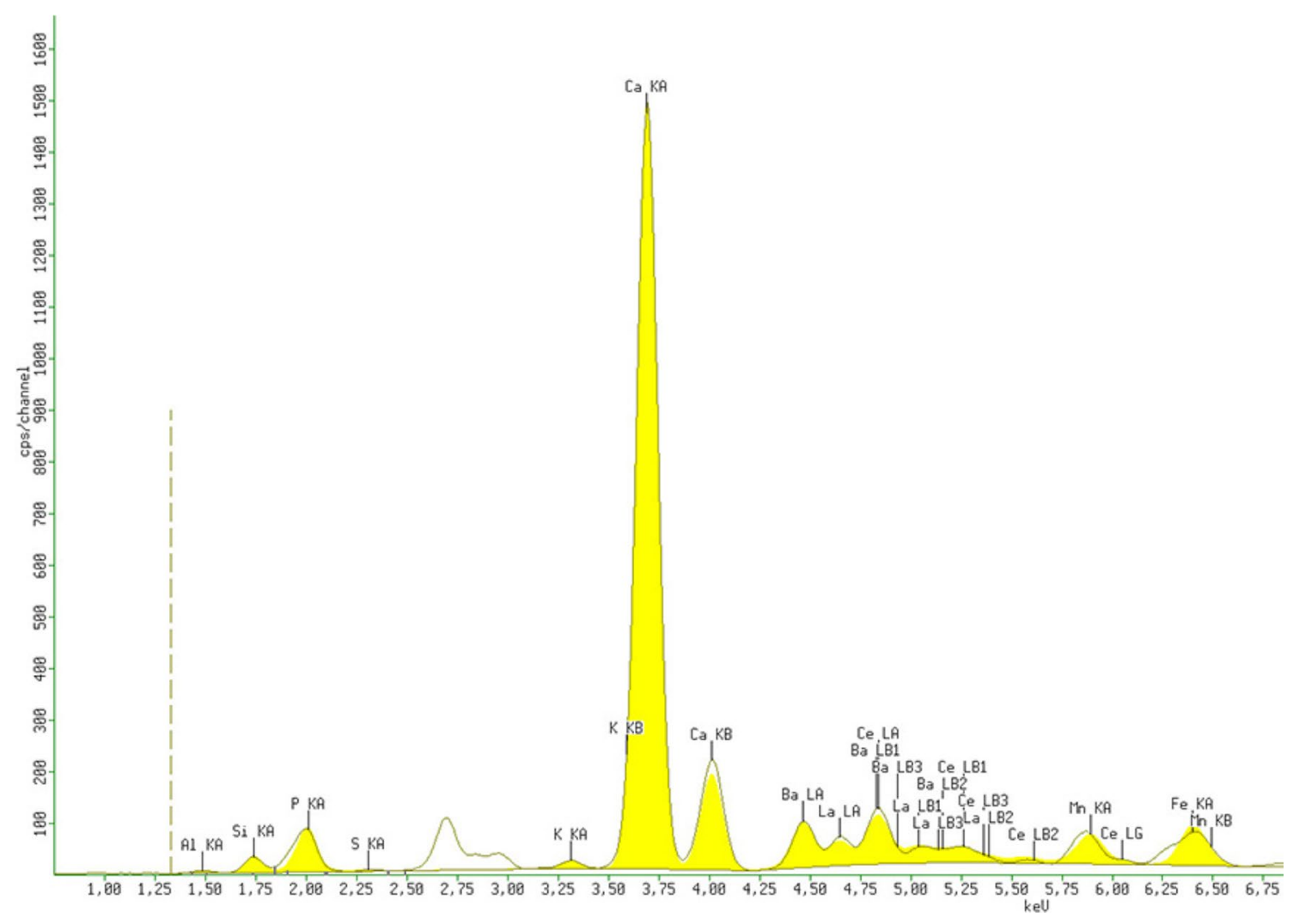

Fig. 10 Results of EDS analysis for phosphogypsum 


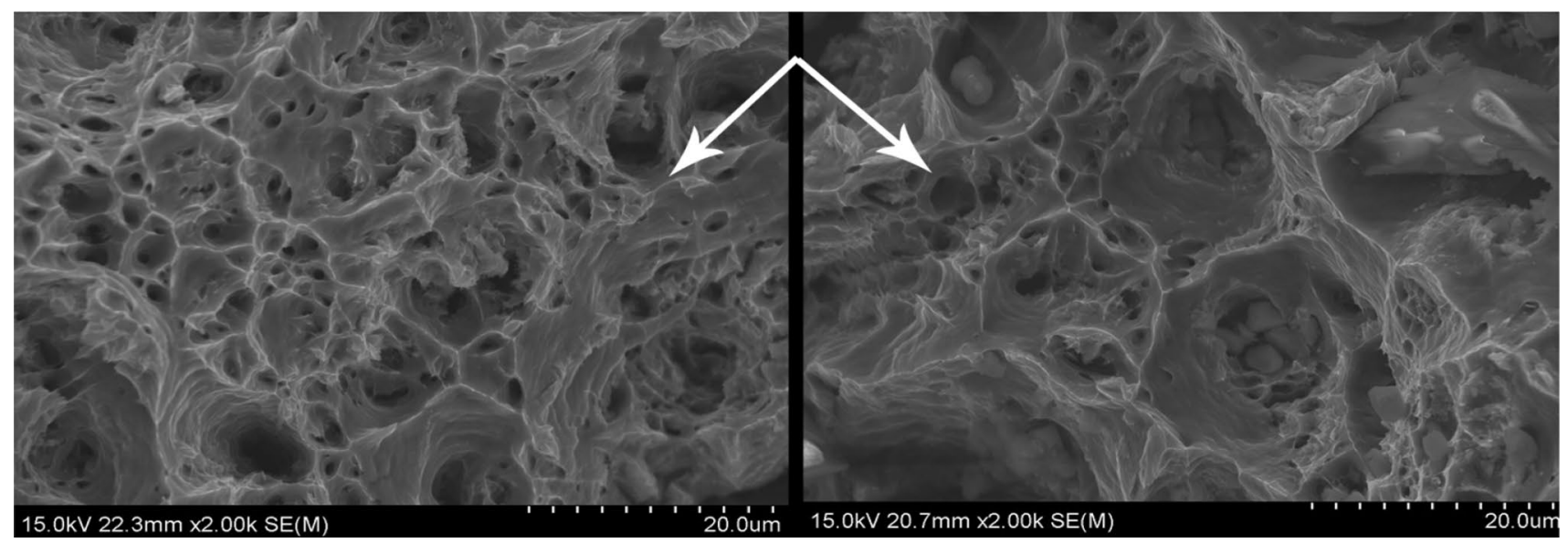

Fig. 11 The difference between the morphology of the sharp walls of composite made of pure aluminum powder (figure on the left) and the expanded walls of the composite with added $5 \%$ phosphogypsum

\section{Summary}

An effect of hydrated calcium sulfate on the tensile strength of composite showed a tendency to increase the porosity as the amount of phosphogypsum additive was increased. The composite materials were characterized by a ductile fracture with large number of microvoids throughout the observed surface. The proposed uses of waste phosphogypsum are beneficial due to environmental protection and elimination of landfilling charges in Poland.

Funding The project is financed under the program of the Minister of Science and Higher Education under the name Regional Initiative of Excellence in 2019-2022 Project Number 003/RID/2018/19.

\section{Compliance with ethical standards}

Conflict of interest The authors declare that they have no conflict of interest.

Open Access This article is distributed under the terms of the Creative Commons Attribution 4.0 International License (http://creativecommons.org/licenses/by/4.0/), which permits unrestricted use, distribution, and reproduction in any medium, provided you give appropriate credit to the original author(s) and the source, provide a link to the Creative Commons license, and indicate if changes were made.

\section{References}

1. Kowalska E, Wielgosz Z, Żubrowska M et al (2004) Application of waste phosphogypsum in thermoplastic and chemosettings composites. J Polim 49(11-12):828-836 (in Polish)

2. Kowalska $E$ (2003) The effect of silanes on the properties of polyolefin composites filled with rubber scrap or phosphogypsum. Przemysł chemiczny 82(8-9):911-914 (in Polish)
3. Czarnowski W, Krechniak J (2002) Urinary fluoride of schoolchildren in Gdansk. Fluoride 35(4):239-243

4. Papageorgiou F, Godelitsas A, Xanthos S et al (2014) Characterization of phosphogypsum deposited in Schistos remediated waste site. In: Merke BJ, Arab A (eds) Uranium past and future challenges. Springer, Cham, pp 271-280

5. Kumar S (2000) Fly ash-lime phosphogypsum cementitious binder: a new trend in bricks. Mater Struct 33:59-64

6. Liang H, Zhang P, Jin Z, DePaoli D (2017) Rare earths recovery and gypsum upgrade from Florida phosphogypsum. Miner Metall Process 34(4):201-206

7. Mikoś J (2000) Synthetic construction gypsum from flue gas desulfurization. In: Construction processes, Silesian Institute of Technology Conference. Gliwice - Kokotek. 28 Sept to 01 Oct 2000 r. pp 147-152 (in Polish)

8. Wissa AE, Fuleihan NF (2000) Phosphogypsum stacks and groundwater protection. Phosphorus and potassium - materials science and engineering collection, No. 227, p 46

9. Hassoune H, Lahhit M, Khalid A, Lachehab A (2017) Application of leaching tests on phosphogypsum by infiltration-percolation. Water Sci Technol 76(7):1844-1851

10. Folek S, Walewska B, Wilczek B, Miśkiewicz J (2011) Use of phosphogypsum in road construction. Pol J Chem Technol 13(2):18-22. https://doi.org/10.2478/v10026-011-0018-5

11. Rashad AM (2017) Phosphogypsum as a construction material. J Clean Prod 166:732-743. https://doi.org/10.1016/j.jclep ro.2017.08.049

12. Ordinance of the Minister of Environment-November 18, 2014. On conditions to be met when introducing sewage into waters or into the ground, and substances particularly harmful to the aquatic environment. 2014r, pp 1-40

13. Mohanty B, Panda D, Rao AS, Sahoo PK (1993) Potential utilization of phosphogypsum. Min Metall Explor 10(3):160-162

14. Biegańska J, Piątkowska E, Pala A (2014) Development of phosphogypsum for non-industrial purposes. Bezpieczeństwo - Jakość - Efektywność. KOMEKO 2014, Instytut Techniki Górniczej; Gliwice, pp 107-117 (in Polish)

15. Mymrin AV, Alekseev KP, Nagalli A, Catai RE, Romano CA (2015) Hazardous phosphor-gypsum chemical waste as a principal component in environmentally friendly construction materials. J Environ Chem Eng 3(4):2611-2618. https://doi.org/10.1016/j. jece.2015.02.027 
16. Wloch G, Skrzekut T, Sobota J, Woznicki A, Cison J (2016) The structure and mechanical properties of plastically consolidated $\mathrm{Al}-\mathrm{Ni}$ alloy. Key Eng Mater 682:245-251

17. Skrzekut T, Kula A, Blaz L (2016) Structure evolution in annealed and hot deformed AIMg- $\mathrm{CeO}_{2}$ composite. Key Eng Mater 682:259-264
Publisher's Note Springer Nature remains neutral with regard to jurisdictional claims in published maps and institutional affiliations. 